\title{
The Spatial Variability of Amazonian Soils under Natural Forest and Pasture
}

\author{
Correa, José C., Research Assistant, UEPAE, EMBRAPA, \\ Manaus, AM, Brazil; \\ Reichardt, Klaus, Prof. Dr., University of Sao Paulo, Piracicaba, SP, Brazil
}

\begin{abstract}
Spatial variability of physical and chemical properties in Amazonian soils is evaluated on sites of natural rain forest and pastures of different age in the Amazon region. The sampling scheme was regionalized using transects of fifty points $3 \mathrm{~m}$ apart each. Variables analysed were: soil bulk density; resistance to penetration; soil water content; available water; $\mathrm{pH}$ and extractable ions such as $\mathrm{Ca}, \mathrm{K}, \mathrm{Al}, \mathrm{P}$ and $\mathrm{Zn}$. Geostatistical analyses show that most variables are space independent for the $3 \mathrm{~m}$ spacing used. Variances indicate a much lower variability of the measured properties in the forest as compared to pastures.
\end{abstract}

\section{Introduction}

The clearing of the natural forest in the Amazon basin using slash and burn procedures and the consecutive introduction of pastures promote a series of alterations in the physical and chemical properties of soils. The anthropogenic impacts on the tropical soils might have positive as well as negative aspects, since they are able to establish the improvement of certain soil properties but, on the other hand, might propel the degradation of others. It is therefore important to understand these alterations in order to define such management systems that maintain or recuperate the agricultural potential of these soils.

The degradation of pastures in the Amazon region has received considerable attention recently (Hecht 1979). The great majority of these pastures (Panicum maximum $L$.) are subject to a severe process of degradation of which the most apparent reasons are: the introduction of species with a high nutrient requirement, the application of fertilization practices unapt for tropical soils and the impact of permanent overgrazing.

In addition, a few reports indicate phoshorus deficiency as one of the main limiting factors for the development of good ranch land (Serrao et al. 1979; EMBRAPA 1981). Chandler (1964) points out that the physical properties of soils and the management practices have also to be considered. Even with the replacement of nutrients, the production potential of pastures falls markedly from year to year subsequent to their establishment, a fact which was also confirmed for the
"Cerrado" conditions of central Brazil (Pedreira et al. 1972). Permanent overgrazing raises significant problems of soil compaction, mainly in fine-textured soils. The pore volume is markedly reduced and the soil aeration decreases. The bulk density of these soils increases which leads to a drastic reduction in productivity.

To understand the processes of degradation of tropical ranch land a great number of physical and chemical soil properties must be considered for process evaluation. Sampling procedures must be optimized to establish a data pool which secures a thorough statistical analysis of the soil parameters. Beckett and Webster (1971) showed that coefficients of variation of several soil properties increased as the sampling area was extended. Several contributors used randomized schemes of sampling, considering each sample independent of the other, many times, without fixed criteria. These approaches do not take into account the relative position of each sampling point, and do not permit the analysis of the structure of variances. The use of systematic or regionalized sampling along transects and/or grids frequently shows a great advantage over the classical sampling schemes. This sampling procedure allows the use of the "Theory of Regionalized Variables" (Matheron 1971). The use of auto-correlation and semi-variogram techniques render the set up of sampling domains by the definition of the degree of dependence of variables in space or time. This theory (TRV) was successfully used in the understanding of variability of physical and chemical properties of soils (Campbell 1978; Vieira et al. 1983; O’Halloran et al. 1985). 

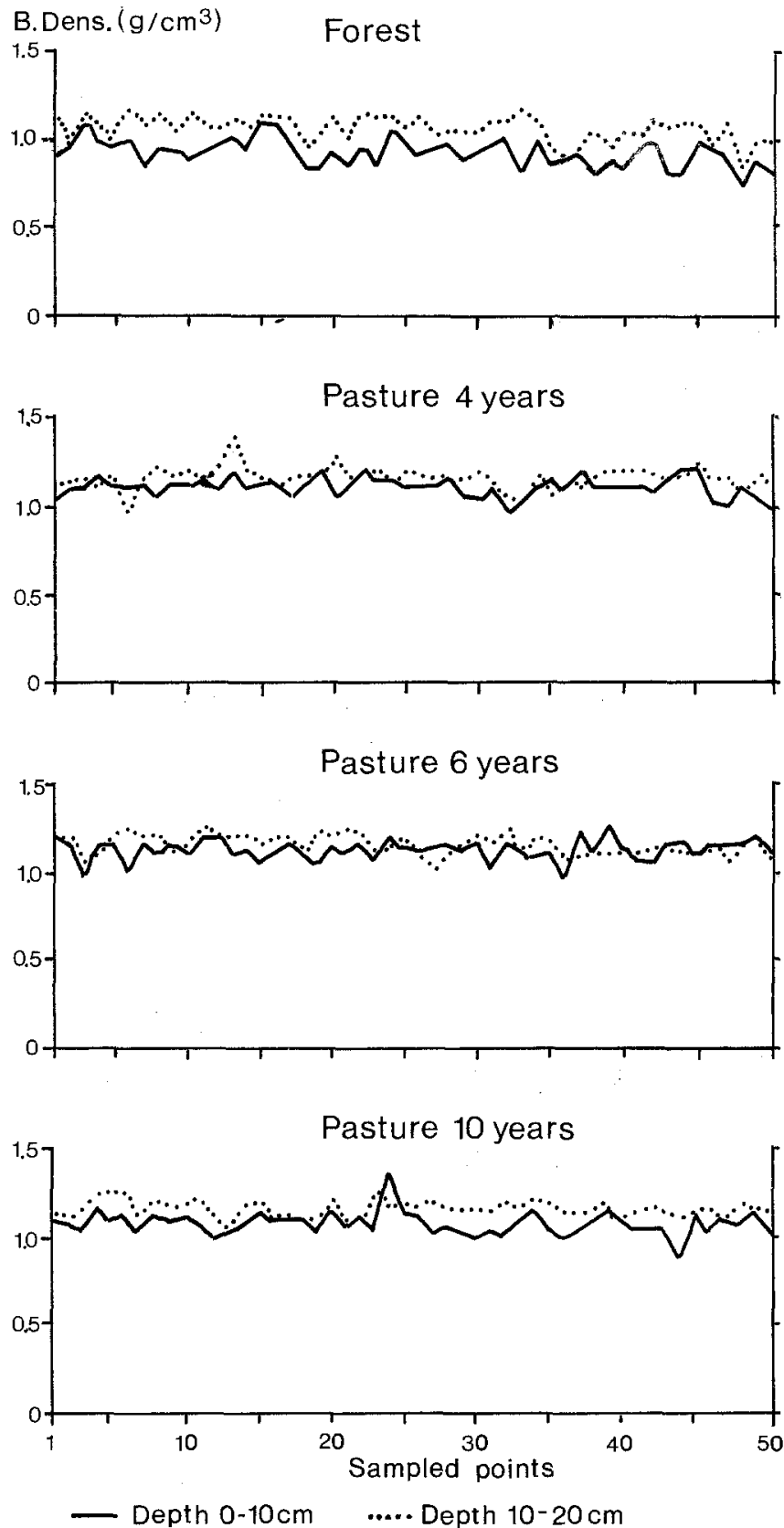

Fig 1 Bulk density of forest and pasture soils

\section{Materials and Methods}

The data presented in this study were collected at the experimental farm of "Empresa Brasileira de Pesquisa Agropecuaria" EMBRAPA (UEPAE, Manaus), located at $\mathrm{km} 54$ of the BR-174 highway (Manaus - Boavista).

The climate at the experimental site is classified as Ami (Koeppen classification). The yearly average of rainfall is in the order of $2100 \mathrm{~mm}$. The yearly average of potential evapotranspiration is at about $1670 \mathrm{~mm}$. There is a significant dry season from June to October.

The most abundant soil type is a very heavy yellow latosol (oxisol) while the matrix is formed by Tertiary
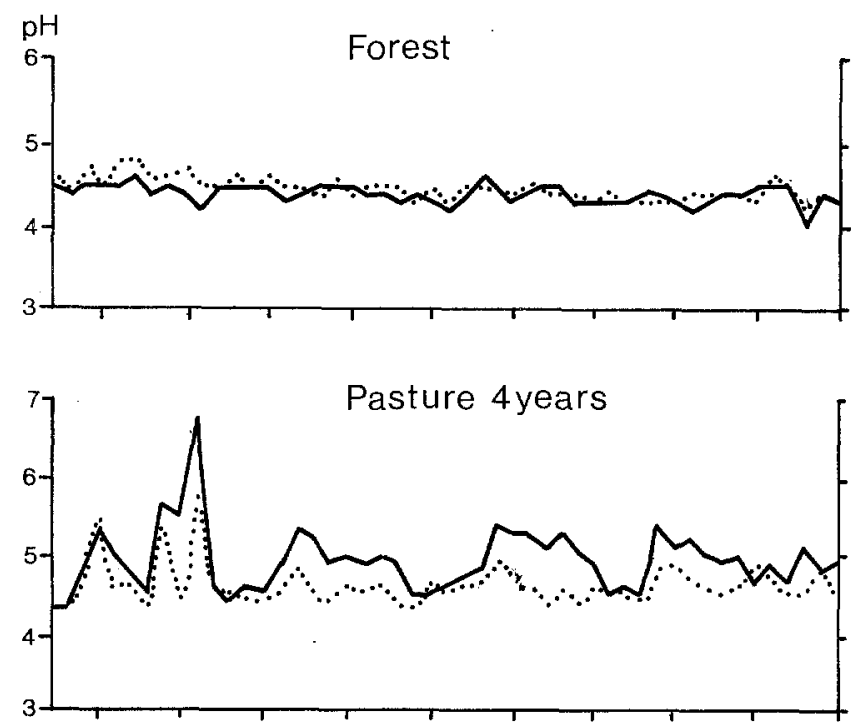

Pasture 6 years
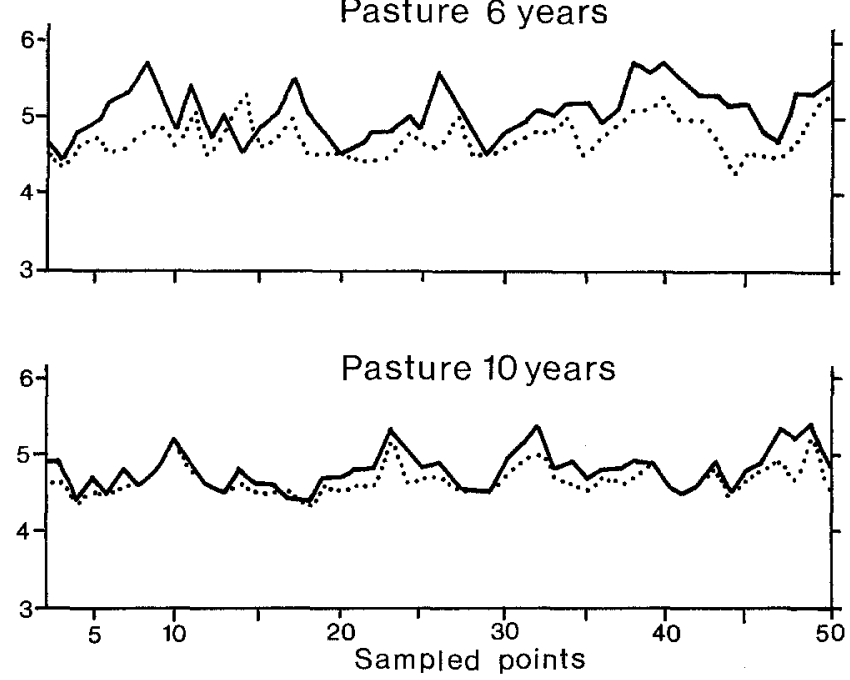

- Depth 0-10 cm $\quad \cdots$ Depth $10-20 \mathrm{~cm}$

Fig 2 Hydrogen-ion concentration (in water) of forest and pasture soils

sediments of the "Barreiras" Series. The latosols are characterized by low nutrient availability, high aluminum saturation and good physical soil properties. The latter render good conditions for the development of pastures and perennial crops in terms of managment practices (Dematte 1988).

This study was carried out on four neighbouring sites: a) primary forest, rich in botanical species, with tallest trees higher than $30 \mathrm{~m}$; b) four year pasture, established in 1984 ; c) six year pasture, established in 1982 , and d) ten year pasture, established in 1978 .

Following the slash and burn practices the pastures were considered to be established 10 months later and then they were stocked with cattle (one animal/ha).

Sampling procedures were selected in order to permit an analysis using geostatistics (Davis 1973; Dutter 1985). 


\begin{tabular}{|c|c|c|c|c|c|c|c|c|c|}
\hline \multirow{3}{*}{$\begin{array}{l}\text { Soil } \\
\text { Property }\end{array}$} & \multirow{3}{*}{$\begin{array}{c}\text { Depth } \\
\frac{(\mathrm{cm})}{}\end{array}$} & \multirow{2}{*}{\multicolumn{2}{|c|}{ Forest }} & \multicolumn{6}{|c|}{ Pastures } \\
\hline & & & & \multicolumn{2}{|c|}{4 Years } & \multicolumn{2}{|c|}{6 Years } & \multicolumn{2}{|c|}{10 Years } \\
\hline & & mean & C.V. $\%$ & mean & $\mathrm{CV} \%$ & mean & C. $\mathrm{V} . \%$ & mean & C. V. $\%$ \\
\hline $\begin{array}{l}\text { Bulk } \\
\text { density } \\
\left(\mathrm{g} / \mathrm{cm}^{3}\right)\end{array}$ & $\begin{array}{c}0-20 \\
10-20\end{array}$ & $\begin{array}{r}0.92 \\
1.06\end{array}$ & $\begin{array}{l}8.6 \\
7.1\end{array}$ & 1.10 & $\begin{array}{l}5.0 \\
5.6\end{array}$ & $\begin{array}{l}1,12 \\
1.15\end{array}$ & $\begin{array}{l}5.5 \\
5.0\end{array}$ & $\begin{array}{l}1.08 \\
1.15\end{array}$ & $\begin{array}{l}6.2 \\
3.9 \\
\end{array}$ \\
\hline $\begin{array}{c}\text { Available } \\
\text { water } \\
(\% \text { vol })\end{array}$ & $\begin{array}{l}0-10 \\
10-20\end{array}$ & $\begin{array}{l}14.5 \\
17.1 \\
\end{array}$ & $\begin{array}{l}25.5 \\
27.3\end{array}$ & $\begin{array}{l}18.0 \\
18.2\end{array}$ & $\begin{array}{l}16.9 \\
18.3\end{array}$ & $\begin{array}{l}22,7 \\
220\end{array}$ & $\begin{array}{l}28.3 \\
25.4\end{array}$ & $\begin{array}{l}17.5 \\
18.5\end{array}$ & 24.8 \\
\hline $\mathrm{pH}$ & $\begin{array}{r}0-10 \\
10-20\end{array}$ & $\begin{array}{l}4.4 \\
4.4 \\
\end{array}$ & $\begin{array}{r}2.6 \\
2.9 \\
\end{array}$ & $\begin{array}{l}4.9 \\
4.6 \\
\end{array}$ & $\begin{array}{l}8.7 \\
6.1\end{array}$ & $\begin{array}{l}5.0 \\
4.7 \\
\end{array}$ & $\begin{array}{l}6.8 \\
5.5 \\
\end{array}$ & $\begin{array}{r}4.7 \\
4.6 \\
\end{array}$ & $\begin{array}{l}5.3 \\
4.4 \\
\end{array}$ \\
\hline $\begin{array}{c}\mathrm{Ca} \\
(\mathrm{me} / 100 \mathrm{~g})\end{array}$ & $\begin{array}{l}0-10 \\
10-20\end{array}$ & $\begin{array}{l}0.09 \\
0.07\end{array}$ & $\begin{array}{l}43.3 \\
32.9\end{array}$ & $\begin{array}{l}0.89 \\
0.27\end{array}$ & $\begin{array}{l}155 \\
207\end{array}$ & $\begin{array}{l}0.81 \\
0.21\end{array}$ & $\begin{array}{l}70.5 \\
67.2\end{array}$ & $\begin{array}{l}0.67 \\
0.28\end{array}$ & $\begin{array}{l}110 \\
902\end{array}$ \\
\hline$(\mathrm{me} / 100 \mathrm{~g})$ & $\begin{array}{l}0-10 \\
10-20\end{array}$ & $\begin{array}{l}0.07 \\
0.04\end{array}$ & $\begin{array}{l}20.4 \\
23.4\end{array}$ & $\begin{array}{l}0.11 \\
0.06\end{array}$ & $\begin{array}{l}65.3 \\
93.3\end{array}$ & $\begin{array}{l}0.22 \\
0.12\end{array}$ & $\begin{array}{l}157 \\
214 \\
\end{array}$ & $\begin{array}{l}0.18 \\
0.09\end{array}$ & $\begin{array}{l}77.8 \\
79.3\end{array}$ \\
\hline$(\mathrm{me} / 100 \mathrm{~g})$ & $\begin{array}{r}0-10 \\
10-20\end{array}$ & 2.1 & $\begin{array}{l}16.6 \\
15.6\end{array}$ & $\begin{array}{l}1.0 \\
1.1\end{array}$ & $\begin{array}{l}53.4 \\
28.8\end{array}$ & $\begin{array}{l}0.98 \\
1,17\end{array}$ & $\begin{array}{l}201 \\
24.9\end{array}$ & 12 & $\begin{array}{l}32.3 \\
32.1\end{array}$ \\
\hline $\begin{array}{c}\mathrm{P} \\
\text { (ppm) }\end{array}$ & $\begin{array}{r}0-10 \\
10-20\end{array}$ & 1,8 & $\begin{array}{l}45.8 \\
94.6\end{array}$ & $\begin{array}{l}33 \\
2.1\end{array}$ & $\begin{array}{l}97.0 \\
182\end{array}$ & $\begin{array}{l}2.8 \\
2.1\end{array}$ & $\begin{array}{l}278 \\
28.3\end{array}$ & $\begin{array}{l}2.6 \\
1.8\end{array}$ & $\begin{array}{l}37.9 \\
40.9\end{array}$ \\
\hline $\begin{array}{c}\mathrm{Zn} \\
(\mathrm{pp})\end{array}$ & $\begin{array}{r}0-10 \\
10-20\end{array}$ & $\begin{array}{l}0.60 \\
0.31\end{array}$ & $\begin{array}{l}32.8 \\
44.2\end{array}$ & $\begin{array}{l}1,53 \\
041\end{array}$ & $\begin{array}{l}84,5 \\
83.3\end{array}$ & $\begin{array}{l}1.31 \\
0.25\end{array}$ & $\begin{array}{l}70.5 \\
60.9\end{array}$ & $\begin{array}{l}1.99 \\
034\end{array}$ & 50.3 \\
\hline
\end{tabular}

Tab 1 Average values and coefficients of variation of several physical and chemical properties of soil under forest and pastures

Therefore samples were taken along transects, with a lag of $3.0 \mathrm{~m}$, totaling 50 sampling points at each site. Each sampling point represented an area of $1 \mathrm{~m}^{2}$ in which collections and measurements were made.

Soil resistance was measured at depth intervals $0-10$ and $10-20 \mathrm{~cm}$, using an EYKELKAMP 70 penetrometer with a $1 \mathrm{~cm}^{2}$ surface cone. Simultaneously, at the same depths, soil samples were collected in order to measure soil water content. Biomass was sampled at pasture sites only, collecting all vegetation of $1 \mathrm{~m}^{2}$. The samples were dryed at $65^{\circ} \mathrm{C}$ and weighed. After plants collection soil samples were taken to determine bulk density (volumetric cylinders of $98.52 \mathrm{~cm}^{3}$ ) and other physical and chemical parameters at the depth of $0-10$ and $10-20 \mathrm{~cm}$ respectively.

Physical analysis included the measurements of soil water retention at several potentials, and the chemical analyses covered the detection of

a) $\mathrm{pH}$ (water and $\mathrm{KCl}$ );

b) Calcium, Magnesium and Aluminium $(1 \mathrm{~N} \mathrm{KCl})$;

c) Potassium, Phosphorus, Zinc, Copper, Iron and Manganese (acid digestion: $0.025 \quad \mathrm{~N}_{2} \mathrm{H}_{2} \mathrm{SO}_{4}$ and $0.05 \mathrm{~N} \mathrm{HCl}$ ).

\section{Results and Discussion}

A geostatistical analysis was performed on all data using auto-correlation technique. Almost all auto-corre- lograms showed no spatial dependence for distances greater than the lag of $3 \mathrm{~m}$. The few significant ones were spatial dependent only for one or two lags and with $\mathrm{r}$ lower than $0.5 \mathrm{~m}$. This indicates the spatial independence of the measurements. All distributions were normal or very close to normal.

The surface bulk density of natural forest soils is insignificantly lower than in the deeper layer $(10-20 \mathrm{~cm}$ ), along the whole transect (Fig 1). Several points show values below $0.9 \mathrm{~g} / \mathrm{cm}^{3}$. For the pasture sites the bulk density of both layers shows higher values than those observed in the forest (Fig 5, Tab 1), all having low coefficients of variation.

The resistance to penetration data, shown as averages (Fig 5), only display differences that indicate an increase of compaction with pasture age for the top layers. This might be due to the increase in bulk density and the decrease in soil water content which was measured simultaneously with resistance (Fig 5).

Available water (estimated from laboratory soil water characteristics using soil water potentials of $0.1 \mathrm{~atm}(10 \mathrm{kPa})$ and $15 \mathrm{~atm}(1.5 \mathrm{MPa}))$ showed an increase from the forest to the six year pasture, and then a decrease for the ten year pasture (Tab 1).

With regard to chemical properties of the soils the variability of parameters of natural forest soils are significantly lower than those of the pastures (Fig 2, $3 \& 4$ ). The coefficients of variation are more than double for the pastures when compared to the forest (Tab 1). Some 

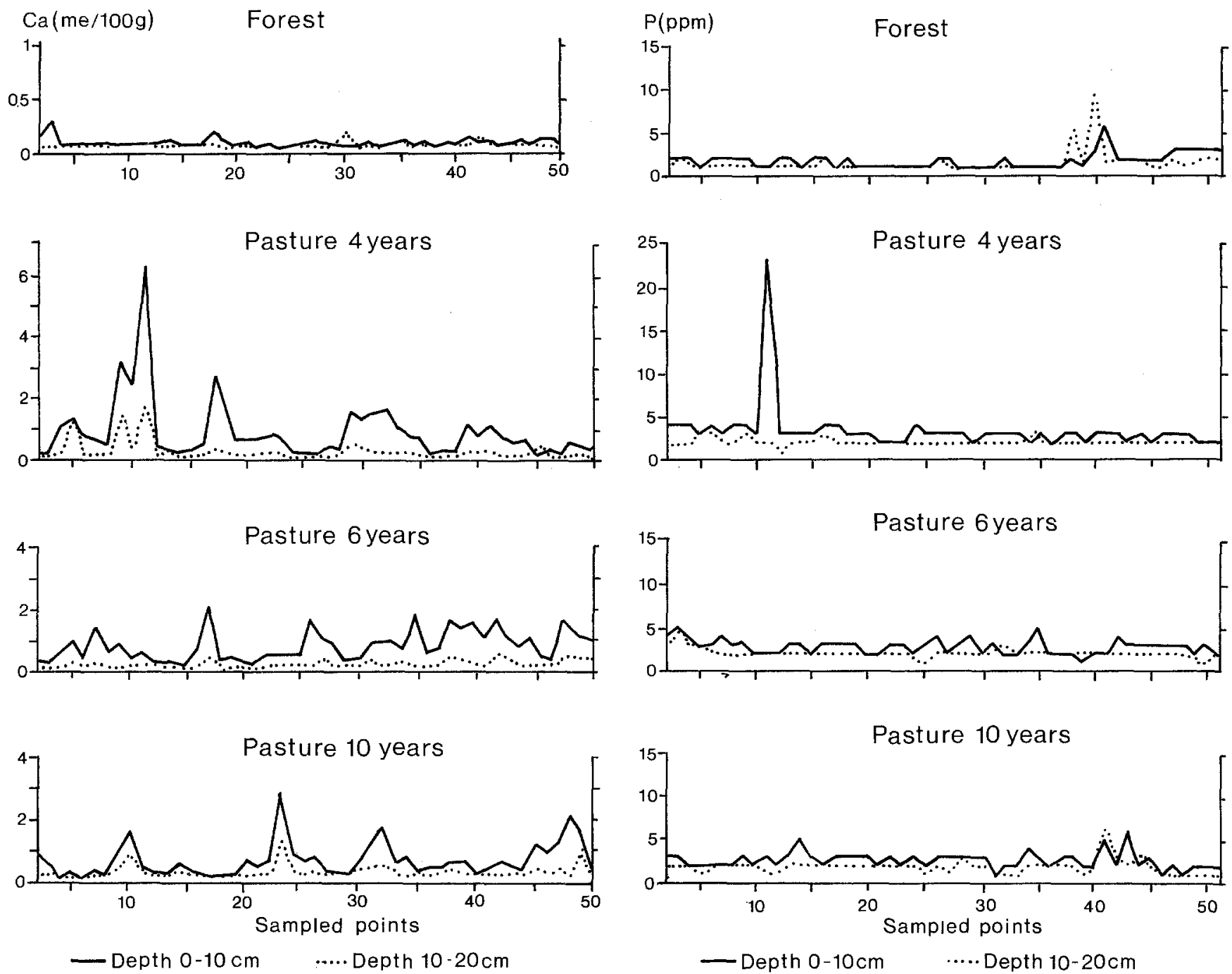

Fig 3 Extractable calcium content of forest and pasture soils

Fig 4 Extractable phosphorus content of forest and pasture soils

of the coefficients are extremely high (over 100\%) which reveals a serious sampling problem. The high variability of pastures could be a consequence of the burning of root-stocks which concentrate a high ash content at such places.

Average soil $\mathrm{pH}$ (water) measurements increase slightly passing from forest to pastures. The top layer nutrients increase markedly in pastures and do not show a significant decrease with time. Phosphorus (Fig 4), a deficiency of which is considered to cause the degradation of pasture almost doubled in the four year pasture, but had a slight decrease over time. The concentrations of phosphorus, however, are lower than the critical values for grassland $(5-10 \mathrm{ppm})$ as reported by Werner and Haag (1972). Phosphorus plays an important role in the development of grass root systems and it might be a limiting factor for the productive capacity of these soils.

The analysis of the data of this study shows the difficulty to determine the reasons of the degradation of the pastures. The effects of the variability of the physical

and chemical properties of tropical soils and the sampling procedures must be considered in conjunction. Management practices and grazing intensities also play an important role in the establishment and maintenance of pastures.

\section{Conclusions}

The study, which compares the variation of physical and chemical parameters of natural rain forest sites and cleared land under pasture, produces some evidence that the bulk density of the top soil layers of land under pasture increases significantly.

There is evidence that pasture land receives an increase of extractable nutrients also. The study demonstrates the degradation of pasture land to be a very complex process which involves a great number of physical and chemical soil properties but also land management practices. 

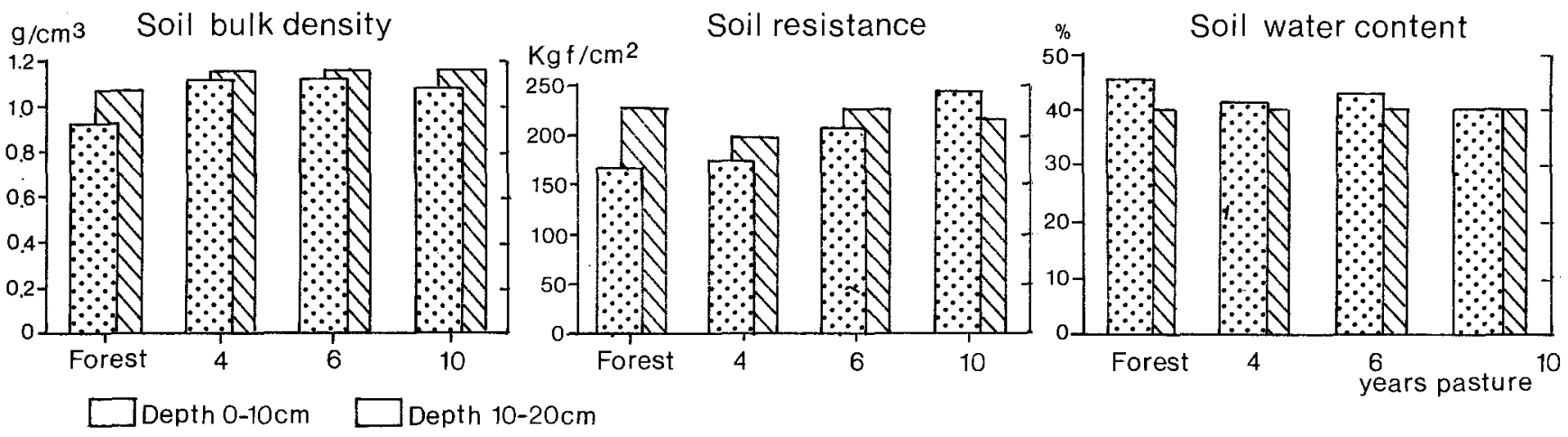

Fig 5 Physical properties of forest and pasture soils

\section{Acknowledgement}

The International Atomic Energy Agency, Vienna is gratefully acknowledged for financial support under Project BRA-010.

\section{References}

Campbell, J. B.: Spatial variability of sand content and $\mathrm{pH}$ within single continuous delineations of two soil mapping units. Soil Sci. Soc. Amer. Proc. 42: 460-464 (1978)

Chandler, J. V.; Costa, R. C.; Pearson, R. N.; Abruca, F.; Figarella, J.; Silva, S.: The intensive management of tropical forages in Puerto Rico. Bull 18, Univ. P. Rico, Agric. Exp. Station, 1964.

Davis, J. C.: Statistics and Data Analysis in Geology. John Wiley \& Sons, New York 1973.

Dematte, J. L. I.: Management of Acid Soils of the Humid Tropics - Amazon Region. 215 p. Cargill Foundation, Campinas 1988.

Dutter, R.: Geostatistik, eine Einführung mit Anwendungen. B. G. Teubner, Stuttgart 1985.
EMBRAPA: Relatório Técnico Anual da UEPAE de Manaus (EMBRAPA/UEPAE de Manaus). Brasilia, DF, 28-29, 1981.

Hecht, S. B.: In: Sanches, P. A.; Tergas, L. E. (eds.), Pasture Production in Acid soils of the Tropics. 65-80. Ciat, Cali, Colombia 1979.

Matheron, G.: The Theory of Regionalised Variables and its Applications. Les Cahiers du Centre de Morphologie Mathematique de Fontainebleau, France (1971)

O'Halloran, I. P.: Kachanoshi, R. G.; Stewart, J. W. B.: Spatial variability of soil phosphorus as influenced by soil texture and management. Can. J. Soil. Ottawa, 65: 475-487 (1985)

Pedreira, J. V. S.: Stational growth development of grasses Panicum maximum, Melinis minutiflora, Hyparrhenia rufa and Digitaria pentzii. PhD. dissertation. 117 p. University of Sao Paulo, Piracicaba 1972.

Serrao, E. A. S.; Falesi, I. C.; Beiga, J. B.; Teixeira, J. F.: Productivity of cultivated pastures in low fertility soils of the Amazon of Brazil. In: Sanchez, P. A.; Tergas, L. E. (eds.), Pasture Production in Acid Soils of the Tropics. Centro Internacional de Agricultura Tropical, Cali, Colombia 1979.

Vieira, S. R.; Hatfield, J. L.; Nielsen, D. R.; Biggar, J. W.: Geostastical theory and, application to variability of some agronomical properties. Hilgradia 3 (1983)

Werner, J. C.; Haag, H. P.: Mineral nutrition of several tropical grasses. Bol. Ind. Anim. Nova Odessa 29, 1, 191-245 (1972) 